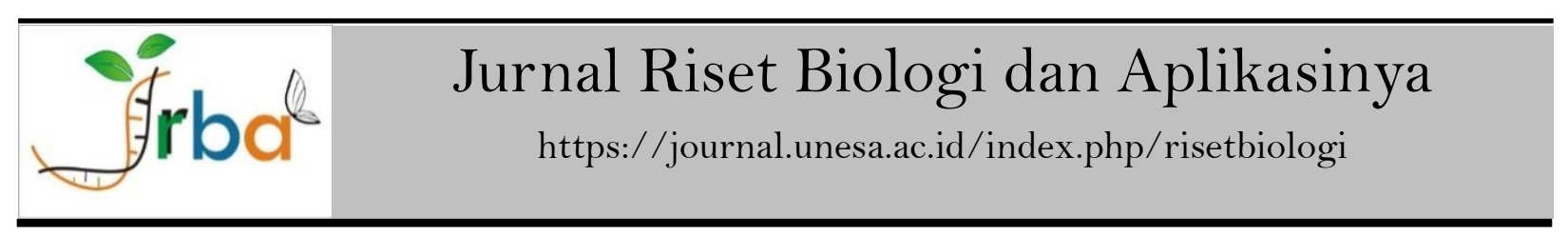

\title{
Karakterisasi Enzim Amilase dari Bakteri Bacillus megaterium pada Variasi Suhu, pH dan Konsentrasi Substrat
}

\author{
Characterization of Amylase Enzyme from Bacillus megaterium Bacteria on Various \\ Temperature, $p H$ and Substrate Concentration \\ Dina Istia'nah*, Ulfah Utami, Ahmad Barizi \\ Jurusan Biologi, Fakultas Sains dan Teknologi, Universitas Islam Negeri Maulana Malik Ibrahim Malang
}

\begin{tabular}{l} 
Article History \\
\hline Received : 6 Desember 2019 \\
Approved : 20 Februari 2020 \\
Published : 31 Maret 2020
\end{tabular}

Kata Kunci: Bacillus megaterium, enzim amylase, suhu, $\mathrm{pH}$, substrat

Keywords: Bacillus megaterium, amylase enzyme, temperature, $p H$, substrate

\begin{abstract}
Abstrak
Bacillus megaterium merupakan salah satu mikroorganisme potensial yang dapat menghasilkan enzim amilase. Karakterisasi enzim amilase dapat membantu mengetahui kondisi optimum enzim saat bekerja. Penelitian ini bertujuan untuk mengetahui karakteristik enzim amilase yang dihasilkan oleh Bacillus megaterium pada variasi suhu, pH dan konsentrasi substrat. Karakterisasi enzim ditentukan dengan menguji aktivitas enzim pada tiga variasi yakni variasi suhu dengan menggunakan $\mathrm{pH}$ netral, variasi $\mathrm{pH}$ yang dilakukan pada kondisi suhu optimum hasil perlakuan sebelumnya dan variasi konsentrasi substrat YPSs yang dilakukan pada kondisi suhu dan $\mathrm{pH}$ optimum hasil perlakuan sebelumnya. Data aktivitas enzim amilase dianalisis secara deskriptif dengan menentukan nilai aktivitas enzim amilase tertinggi pada setiap perlakuan. Hasil penelitian ini menunjukkan bahwa Bacillus megaterium mampu menghasilkan enzim amilase. Indeks Aktivitas Amilase (IAA) Bacillus megaterium sebesar 2,35 mm. Secara kuantitatif aktivitas enzim amilase ditentukan dengan metode DNS yang untuk mengukur kadar gula reduksi yang diproduksi oleh mikrob dengan tingkat ketelitian yang tinggi. Ekstrak kasar enzim amilase yang diproduksi oleh Bacillus megaterium memiliki karakteristik pada suhu $37^{\circ} \mathrm{C}$ dengan aktivitas enzim sebesar $1,279 \mathrm{U} / \mathrm{mL}$, sedangkan karakteristik $\mathrm{pH}$ berada pada $\mathrm{pH}$ 5,0 dengan aktivitas enzim sebesar 1,241 $\mathrm{U} / \mathrm{mL}$ dan karakteristik konsentrasi substrat berada pada konsentrasi $1,50 \%$ dengan aktivitas enzim sebesar $0,548 \mathrm{U} / \mathrm{mL}$.
\end{abstract}

\begin{abstract}
Bacillus megaterium is one of potential microorganisms that can produce amylase enzyme. Characterization of an amylase enzyme is useful to determine the optimum condition of the enzyme. This study aimed to determine the characteristics of amylase enzyme from Bacillus megaterium on various temperature, $p H$ and substrate concentration. Characterization of the enzyme was determined by testing the enzyme activity at various temperatures by using a neutral $p H$. Various $p H$ conducted at an optimum temperature from the previous treatment and the variety of substrate concentration $\mathrm{YPSS}$ conducted under optimum temperature and $\mathrm{pH}$ condition from the previous treatments. Amylase enzyme activity data were analyzed descriptively to determine the value of the highest amylase enzyme activity in each treatment. The results of this study showed that Bacillus megaterium are able to produce the amylase enzyme. The Amylase Activity Index (IAA) Bacillus megaterium was $2.35 \mathrm{~mm}$. The enzyme activity quantitatively determined by the DNS method for measuring the reduction of sugar levels produced by microbes with a high level of precision. The crude extract of amylase enzyme produced by Bacillus megaterium had characteristic of temperature of $37^{\circ} \mathrm{C}$ with the enzyme activity of $1.279 \mathrm{U} / \mathrm{mL}$. The characteristic of $\mathrm{pH}$ was 5.0 with the enzyme activity $1.241 \mathrm{U} / \mathrm{mL}$. The characteristic of the substrate concentration was at a substrate concentration of 1,50\% with the enzyme activity of $0.548 \mathrm{U} / \mathrm{mL}$.
\end{abstract}

How to cite: Istia'nah, D., Utami, U \& Barizi, A. 2020. Karakterisasi Enzim Amilase dari Bakteri Bacillus megaterium pada Variasi Suhu, pH dan Konsentrasi Substrat. Jurnal Riset Biologi dan Aplikasinya, 2(1), 11-17. 


\section{PENDAHULUAN}

Industri enzim telah berkembang pesat dan menempati posisi penting dalam bidang industri. Penggunaan enzim semakin meningkat dari tahun ke tahun hingga mencapai 10-15\% (Mufarrikha et al., 2014). Kegunaan utama enzim bagi organisme adalah sebagai katalis hayati. Namun, kebutuhan enzim di Indonesia masih belum dapat terpenuhi dengan baik sehingga Indonesia masih harus mengimpor enzim (Naiola, 2002). Hal tersebut menyebabkan para peneliti untuk lebih meningkatkan kemajuan dalam bidang teknologi, salah satunya dengan memanfaatkan peran mikroorganisme dalam bidang industri.

Enzim amilase merupakan enzim yang mampu menghidrolisis amilum dan menghasilkan glukosa. Enzim amilase dapat dihasilkan oleh semua makhluk hidup untuk mengkatalis reaksi biokimia, sehingga reaksi-reaksi tersebut dapat berlangsung lebih cepat. Enzim amilase untuk kebutuhan industri diekstraksi dari berbagai jenis sel mahluk hidup, tetapi pada saat ini enzim lebih banyak diekstraksi dari berbagai jenis mikroorganisme, sebab mikroorganisme menghasilkan enzim yang dapat dimanfaatkan manusia dalam jumlah dan jenis yang sangat bervariasi. Selain itu, mikroorganisme dapat dikultur untuk memperoleh enzim yang dihasilkan (Ningsih et al., 2012).

Genus bakteri yang termasuk kelompok bakteri amilolitik di antaranya Bacillus, Clostridium, Bacteriodes, Lactobacillus, Micrococcus, Thermus, dan Actinomycetes (Reddy et al., 2003). Bakteri yang banyak dimanfaatkan sebagai produksi enzim amilase adalah dari golongan genus Bacillus. Salah satu bakteri yang digunakan untuk produksi enzim amilase yakni Bacillus megaterium. Tu et al., (2015) menjelaskan bahwa penggunaan Bacillus megaterium To4 dapat menghasilkan aktivitas enzim amilase sebesar 174,7 U/mL menggunakan media tepung gandum dengan masa inkubasi selama 72 jam.

Bacillus megaterium dapat dengan mudah ditemukan di berbagai tempat karena bakteri tersebut dapat tumbuh pada suhu $3{ }^{\circ} \mathrm{C}$ sampai $45^{\circ} \mathrm{C}$ (De Vos, 2009). Selain itu B. megaterium juga termasuk ke dalam bakteri endofit. Bakteri ini banyak ditemukan pada permukaan daun. Bakteri endofit adalah bakteri yang hidup di dalam jaringan tanaman inang tanpa menyebabkan penyakit. Bakteri endofit masuk ke dalam jaringan tanaman umumnya melalui akar, namun bagian tanaman yang terpapar udara langsung seperti bunga, batang, daun dan kotiledon juga dapat menjadi jalur masuk bakteri endofit (Desriani et al., 2014).
Produksi enzim amilase yang tinggi, tidak lepas dengan adanya faktor-faktor yang mendukung keberhasilan produksi suatu enzim. Faktor yang sangat terpenting adalah suhu, $\mathrm{pH}$ dan substrat yang mengandung kadar pati tinggi. Suhu sangat memengaruhi aktivitas enzim karena enzim adalah rangkaian asam amino yang sistem kerjanya berkaitan erat dengan suhu lingkungan (Tarigan et al., 2015). Aktivitas enzim juga akan dipengaruhi oleh pH. pH akan berkaitan dengan keberadaan ion hidrogen. Konsentrasi ion hidrogen sangat memengaruhi aktivitas enzim, karena enzim dapat aktif apabila asam amino yang merupakan sisi aktif enzim berada dalam keadaan ionisasi yang tepat. $\mathrm{pH}$ terlalu asam atau basa akan menyebabkan enzim terdenaturasi sehingga enzim tidak aktif (Supriyanti \& Poedjiadi, 2007).

Faktor berikutnya yang perlu diperhatikan dalam memproduksi enzim amilase dari bakteri adalah konsentrasi substrat yang digunakan harus mengandung kadar pati yang tinggi. Bakteri sangat membutuhkan substrat untuk mendegrasi pati menjadi karbohidrat yang lebih sederhana (Maarel., 2002). Untuk menentukan aktivitas enzim amilase dapat dilakukan dengan menggunakan substrat yang spesifik, kemudian aktivitas enzim amilase dapat diukur dengan memantau jumlah glukosa pereduksi yang dihasilkannya.

Berdasarkan latar belakang tersebut, dapat diketahui bahwa enzim amilase yang dihasilkan oleh bakteri memiliki rentan suhu, $\mathrm{pH}$ dan konsentrasi substrat yang optimum dengan kondisi lingkungan yang berbeda-beda. Oleh karena itu, perlu dilakukan penelitian lebih lanjut untuk mengetahui karakterisasi enzim amilase yang dihasilkan oleh Bacillus megaterium pada variasi suhu, $\mathrm{pH}$ dan konsentrasi substrat, agar nantinya hasil dari produk enzim amilase dapat diaplikasikan pada industri dengan skala yang lebih besar.

\section{BAHAN DAN METODE}

Penelitian ini menggunakan rancangan acak lengkap. Penelitian ini terdiri atas tiga perlakuan dan setiap perlakuan diulang sebanyak tiga kali. Perlakuan pertama yakni variasi suhu yang terdiri atas suhu $25^{\circ} \mathrm{C}, 27^{\circ} \mathrm{C}, 35^{\circ} \mathrm{C}, 37^{\circ} \mathrm{C}$ dan $45^{\circ} \mathrm{C}$. Perlakuan kedua yakni variasi $\mathrm{pH}$ yang meliputi $\mathrm{pH}$ $4,5,6,7$, dan 8 serta perlakuan ketiga yakni variasi konsentrasi substrat yang terdiri atas $1 \%, 1,25 \%$, $1,50 \%, 1,75 \%$ dan $2 \%$.

Bakteri Bacillus megaterium yang digunakan dalam penelitian ini, diisolasi dari daun kenikir (Cosmos sulphureus Cav.). 
Pengujian secara kualitatif dilakukan untuk mengetahui adanya enzim amilase pada bakteri yang diuji. Pengujian ini dilakukan dengan cara mencampurkan media Yeast Pepton Starch Soluble (YPSs) dengan $100 \mathrm{~mL}$ aquades (Naiola, 2001). Kemudian koloni bakteri digoreskan pada media YPSs yang telah memadat dan diinkubasi pada suhu $37^{\circ} \mathrm{C}$ di dalam inkubator selama 2 hari (Soeka, 2015). Adanya aktivitas enzim amilase dapat dilihat dengan munculnya zona bening di sekitar koloni bakteri setelah dituang dengan larutan iodin (Naiola, 2011).

Diameter zona bening diukur dan digunakan untuk menghitung rasio zona bening dengan rumus berikut (Sudiana, 2002).

$$
\text { Ratio Zona Bening }(\mathrm{ZB})=\frac{\text { Diameter Zona Bening }(\mathrm{DZB})}{\text { Diameter Koloni Bakteri }(\mathrm{DKB})}
$$

Pembuatan kurva pertumbuhan bakteri dan aktivitas amylase dilakukan dengan tahapan berikut. Sebanyak 2 ose Bacillus megaterium hasil peremajaan diinokulasikan ke dalam $150 \mathrm{ml}$ media YPSs cair. Inokulum diinkubasi pada shaker inkubator dengan kecepatan $150 \mathrm{rpm}$ pada suhu $30^{\circ} \mathrm{C}$ selama 24 jam. Inokulum diambil $15 \mathrm{ml}$ dan dipindahkan ke dalam $150 \mathrm{ml}$ media YPSs cair yang baru. Inokulum diambil $10 \mathrm{ml}$ setiap 24 jam sekali dan diukur jumlah sel serta aktivitas amilasenya. Kurva pertumbuhan ditentukan dengan membuat plot antara waktu, absorbansi dengan panjang gelombang $540 \mathrm{~nm}$ menggunakan spektrofotometer dan aktivitas enzim. Aktivitas amilase ditentukan dengan mengukur kadar glukosa dengan metode DNS.

Produksi ekstrak kasar enzim amilase dilakukan dengan cara mengambil 2 ose koloni bakteri yang berumur 24 jam, kemudian dimasukkan ke dalam $100 \mathrm{ml}$ media inokulum yang telah disterilkan. Selanjutnya media yang mengandung koloni bakteri diinkubasi menggunakan shaker inkubator pada suhu $30{ }^{\circ} \mathrm{C}$ selama 120 jam dengan kecepatan 150 rpm (Ajayi $\xi^{\circ}$ Fagade, 2006). Ekstraksi enzim amilase dilakukan dengan cara mengambil kultur bakteri yang telah diinkubasi di dalam shaker inkubator, kemudian kultur bakteri tersebut disentrifugasi dengan suhu 4 ${ }^{\circ} \mathrm{C}$ pada kecepatan $10.000 \mathrm{rpm}$ selama 10 menit. Supernatan yang diperoleh merupakan ekstrak kasar enzim amilase.

Penentuan suhu optimum enzim amilase dilakukan dengan cara mereaksikan $1 \mathrm{ml}$ enzim amilase dengan $1 \mathrm{ml}$ substrat YPSs pada suhu 25
${ }^{\circ} \mathrm{C}, 27{ }^{\circ} \mathrm{C}, 35^{\circ} \mathrm{C}, 37{ }^{\circ} \mathrm{C}$ dan $45^{\circ} \mathrm{C}$ ke dalam buffer fosfat $0,05 \mathrm{M} \mathrm{pH} 7,0$ dan diinkubasi dalam water bath selama 15 menit. Aktivitas enzim amilase dilakukan dengan mereaksikan ekstrak kasar enzim amilase pada variasi suhu. Suhu optimum yang didapatkan digunakan untuk menentukan $\mathrm{pH}$ optimum enzim amilase.

Penentuan pH optimum enzim dilakukan dengan mereaksikan $1 \mathrm{ml}$ ekstrak kasar enzim amilase dengan $1 \mathrm{ml}$ substrat YPSs pada suhu optimum dan sesuai $\mathrm{pH}$ perlakuan. Kemudian diinkubasi ke dalam water bath selama 15 menit (Sari, 2010). Variasi pH dilakukan dengan penambahan buffer sitrat 0,2 $\mathrm{M} \mathrm{pH} 4,5,6$, buffer fosfat $0,2 \mathrm{M} \mathrm{pH} \mathrm{7,} \mathrm{buffer} \mathrm{Tris-HCl} 0,2 \mathrm{M} \mathrm{pH} 8$. Aktivitas enzim amilase dilakukan dengan mereaksikan ekstrak kasar enzim amilase pada variasi $\mathrm{pH}$.

Penentuan konsentrasi substrat optimum aktivitas enzim amilase dilakukan dengan mereaksikan $1 \mathrm{ml}$ ekstrak kasar enzim amilase dan 1 $\mathrm{mL}$ substrat YPSs dengan konsentrasi yang berbeda yaitu 1,0\%, 1,25\%, 1,50\%, 1,75\% dan 2,0\% pada suhu dan $\mathrm{pH}$ optimum. Diinkubasi dalam water bath selama 15 menit. Aktivitas enzim amilase dilakukan dengan mereaksikan ekstrak kasar enzim amilase pada variasi konsentrasi substrat.

\section{HASIL DAN PEMBAHASAN}

Pengujian aktivitas enzim amilase secara kualitatif dapat diketahui dengan mengamati zona bening yang berada di sekitar koloni bakteri. Hasil dari pengujian secara kualitatif menunjukkan bahwa bakteri Bacillus megaterium membentuk zona bening, artinya bakteri tersebut mampu menghasilkan enzim amilase. Zona bening pada Bacillus megaterium dapat diamati pada Gambar 1.

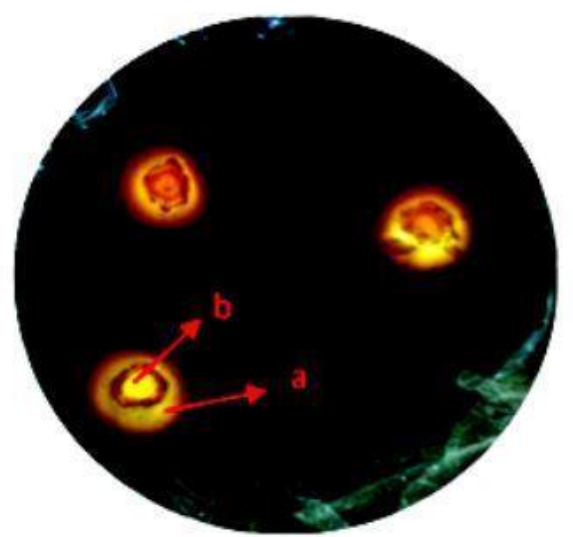

Gambar 1. Zona bening yang dihasilkan oleh bakteri Bacillus megaterium yang dapat memproduksi enzim amilase setelah diinkubasi selama 24 jam.

Keterangan: a: zona bening dan b: Koloni bakteri Bacillus megaterium. 
Aktivitas enzim amilase ekstraseluler dapat diukur berdasarkan diameter zona bening yang terbentuk di sekitar koloni Bacillus megaterium dengan menggunakan rumus Indeks Aktivitas Amilase (IAA). Indeks Aktivitas Amilase pada isolat Bacillus megaterium yang diinkubasi selama 24 jam sebesar 2,35 mm dan dapat dikatakan bahwa isolat bakteri Bacillus megaterium dapat memproduksi enzim amilase dengan rasio yang sangat tinggi. Menurut Choi et al., (2005), rasio enzim ekstraseluler dengan nilai indeks aktivitas amilase di atas 2 termasuk dalam rasio ekstraseluler tinggi.

Pengujian selanjutnya yakni mencari kurva pertumbuhan bakteri Bacillus megaterium untuk dijadikan sebagai patokan dalam menentukan karakterisasi enzim amilase, pertumbuhan bakteri tertinggi terjadi pada jam ke-72 dengan nilai OD sebesar 12 dan produksi gula reduksi sebesar 8160 ppm serta dapat memproduksi aktivitas enzim amilase sebesar 6,044 U/ml (Gambar 2).

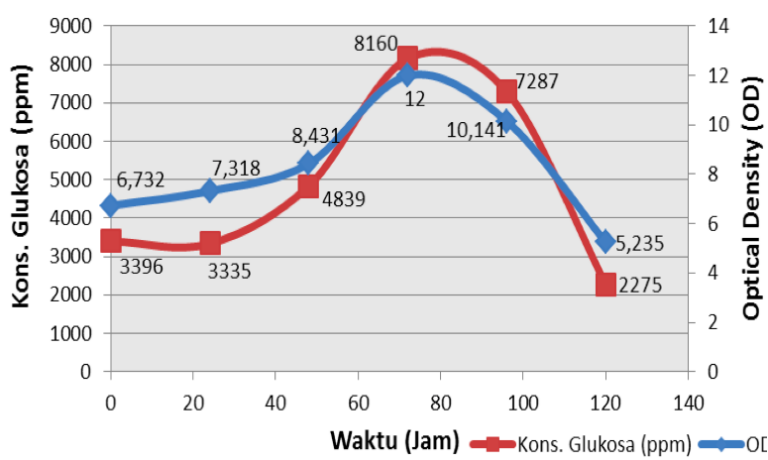

Gambar 2. Kurva pertumbuhan Bacillus megaterium

Hasil tertinggi dari kurva pertumbuhan bakteri Bacillus megaterium digunakan sebagai waktu panen enzim saat proses produksi enzim amilase. Selanjutnya panen enzim amilase pada jam ke-72 tersebut digunakan untuk pengkarakterisasian enzim amilase.

Karakterisasi enzim yang pertama, dilihat dari suhu optimum bakteri dalam memproduksi enzim amilase. Berdasarkan penelitian yang telah dilakukan, didapatkan hasil bahwa suhu optimum bakteri Bacillus megaterium dalam memproduksi enzim amilase yakni pada suhu $37^{\circ} \mathrm{C}$ dengan aktivitas amilase sebesar 1,279 U/mL (Gambar 3).

Karakterisasi enzim yang kedua, dilihat dari $\mathrm{pH}$ optimum bakteri dalam memproduksi enzim amilase. Berdasarkan penelitian yang telah dilakukan, didapatkan hasil bahwa $\mathrm{pH}$ optimum bakteri Bacillus megaterium dalam memproduksi enzim amilase yakni pada $\mathrm{pH}$ 5,0 dengan aktivitas enzim sebesar 1,241 U/ml (Gambar 4).

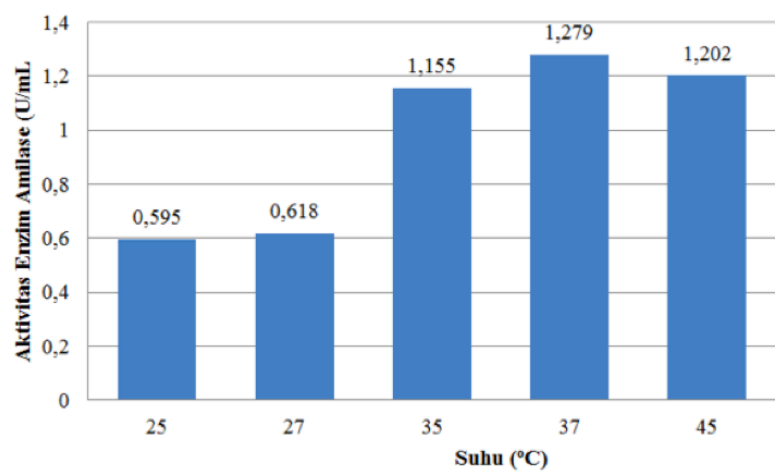

Gambar 3. Pengaruh suhu terhadap aktivitas enzim amilase dengan menggunakan buffer fosfat $\mathrm{pH}$ 7,0.

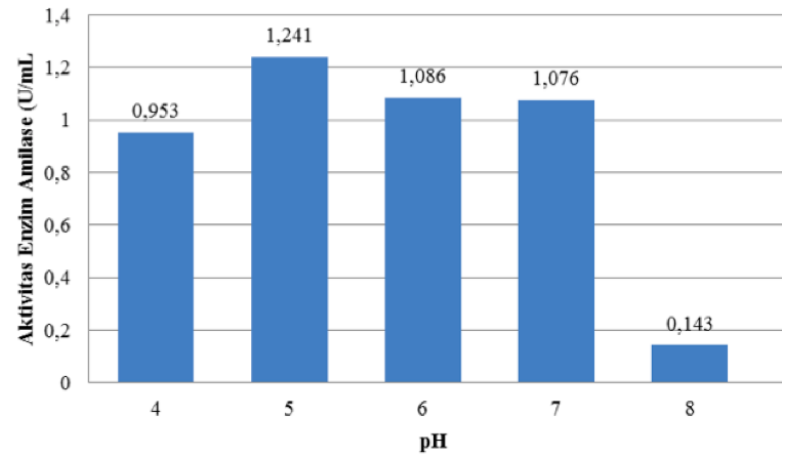

Gambar 4. Pengaruh $\mathrm{pH}$ terhadap aktivitas enzim amilase

Karakterisasi enzim yang ketiga, dilihat dari konsentrasi substrat optimum bakteri dalam memproduksi enzim amilase Berdasarkan hasil penelitian yang dilakukan, maka didapatkan hasil bahwa konsentrasi substrat $1,50 \%$ menjadi konsentrasi substrat yang optimum dengan aktivitas enzim amilase sebesar $0,548 \mathrm{U} / \mathrm{ml}$ (Gambar 5).

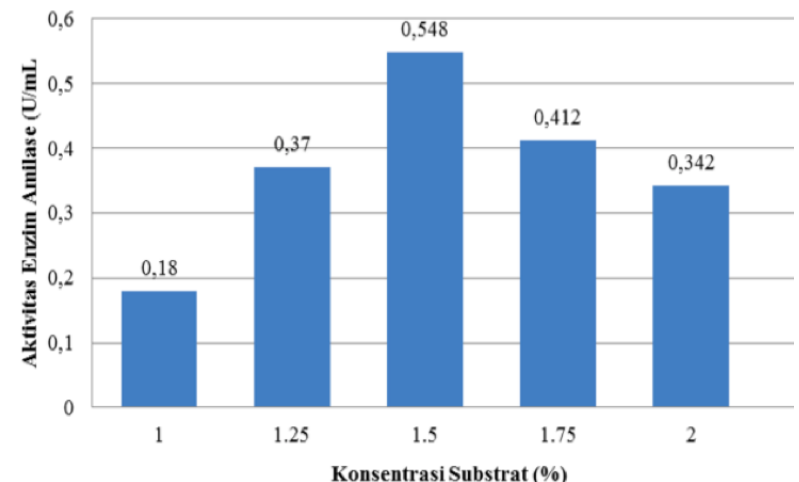

Gambar 5. Pengaruh konsentrasi substrat terhadap aktivitas enzim amilase

Bacillus megaterium merupakan bakteri yang dapat menghasilkan enzim dalam skala yang sangat besar. Banyak ilmuwan telah mengembangkan protein Bacillus megaterium dalam bidang medis dan pertanian. Sebagai contoh, banyak pembuatan 
penisilin sintetik dari bakteri tersebut. Studi bioteknologi banyak membuktikan bahwa protein yang dihasilkan oleh Bacillus megaterium dapat memberikan kemajuan dalam bidang medis, pertanian dan industri (Vary et al., 2007).

Enzim yang dapat dihasilkan oleh Bacillum megaterium yakni enzim amilase. Enzim amilase digunakan untuk menghidrolisis pati menjadi molekul karbohidrat yang lebih sederhana yaitu maltosa dan glukosa. Pati yang belum terhidrolisis sempurna menjadi glukosa juga menghasilkan produk berupa dekstrin. Saat ini produk enzim amilase mencapai skala yang tinggi yaitu sekitar 25\% dari perdagangan enzim (Reddy et al., 2003).

Produksi enzim amilase dapat menggunakan berbagai sumber karbon, misalnya molase, tepung jagung, tepung tapioka dan sebagainya. Dalam produksi enzim amilase dengan menggunakan mikrob, pengendalian terhadap faktor lingkungan sangat penting dilakukan karena dalam produksinya, mikrob dipengaruhi oleh beberapa hal yakni suhu dan lama inkubasi, pH awal, jumlah inokulum dan faktor yang berpengaruh lainnya yang dapat diperoleh melalui eksperimen. Jenis mikrob juga berpengaruh terhadap jumlah enzim yang dihasilkan. Untuk dapat menghasilkan produk enzim amilase dengan kualitas dan kuantitas yang memuaskan, perlu dilakukan optimasi kondisi dan karakterisasi dari bakteri yang digunakan (Dheeran et al., 2009).

Karakterisasi enzim amilase dilakukan dengan mencari suhu, pH dan konsentrasi substrat optimum bakteri dalam memproduksi enzim amilase. Berdasarkan penelitian yang telah dilakukan didapatkan hasil bahwa pada suhu $37^{\circ} \mathrm{C}$, Bacillus megaterium dapat menghasilkan aktivitas amilase sebesar 1,279 U/ml. Menurut Tarigan et al. (2015) menjelaskan bahwa pada suhu optimal, tumbukan antara enzim dan substrat sangat efektif, sehingga pembentukan kompleks enzim-substrat semakin mudah dan produk yang dihasilkan meningkat. Penelitian ini dapat dikatakan sesuai dengan pernyataan Vaseekaran et al. (2010), yang menyatakan bahwa enzim amilase pada umumnya aktif bekerja pada kisaran suhu $25-95^{\circ} \mathrm{C}$.

Hasil penelitian yang kedua yakni karakterisasi enzim amilase berdasarkan $\mathrm{pH}$ optimum bakteri dalam memproduksi enzim amilase. Berdasarkan penelitian yang telah dilakukan, $\mathrm{pH}$ optimum bakteri Bacillus megaterium dalam memproduksi enzim amilase yakni pada $\mathrm{pH}$ 5,0 dengan aktivitas enzim sebesar $1,241 \mathrm{U} / \mathrm{ml}$. pH optimum bakteri dikarenakan protein enzim membentuk struktur yang sangat tepat sehingga enzim dapat mengikat dan mengolah substrat dengan kecepatan yang tinggi. Carvalho et al. (2008), menyebutkan bahwa aktivitas $\mathrm{pH}$ optimum enzim amilase berkisar antara 4,0-8,0.

Ajayi \& Fagade (2006) melaporkan bahwa Bacillus megaterium dapat memproduksi enzim dengan aktivitas sebesar 1,01 U/ml pada $\mathrm{pH} 6,8$. Perbedaan hasil aktivitas enzim amilase dan $\mathrm{pH}$ dari penelitian yang dilakukan dengan penelitian sebelumnya dikarenakan adanya perbedaan prosedur dalam pembuatan buffer $\mathrm{pH}$.

Perubahan $\mathrm{pH}$ dapat menyebabkan perubahan muatan pada molekul enzim sehingga dapat memengaruhi aktivitas enzim, baik dari perubahan struktur maupun perubahan muatan. Selain itu, $\mathrm{pH}$ tinggi ataupun rendah dapat menyebabkan terjadinya denaturasi dan hal tersebut akan mengakibatkan menurunnya aktivitas enzim (Supriyanti \& Poedjiadi, 2007).

Hasil penelitian yang ketiga yakni karakterisasi enzim amilase yang dilihat dari konsentrasi substrat optimum bakteri dalam memproduksi enzim amilase. Berdasarkan hasil penelitian yang dilakukan, maka didapatkan hasil bahwa konsentrasi substrat $1,50 \%$ menjadi konsentrasi substrat yang optimum dengan aktivitas enzim amilase sebesar 0,548 U/mL. Menurut Purwoko (2009), konsentrasi substrat dapat memengaruhi kerja enzim, konsentrasi berbanding lurus terhadap kerja enzim. Dengan kata lain, tingginya konsentrasi substrat akan meningkatkan pula aktivitas enzim. Pada konsentrasi substrat rendah, sisi aktif enzim hanya akan menampung substrat yang sedikit, sedangkan jika konsentrasi substrat diperbesar, maka akan semakin banyak substrat yang akan bergabung dengan enzim pada sisi aktif tersebut sehingga kecepatan reaksi juga akan semakin besar.

Simanjuntak (2003), menjelaskan bahwa semakin banyak konsentrasi substrat maka sisi aktif enzim yang berkontak dengan substrat juga akan bertambah banyak, sehingga semakin banyak amilosa yang dihidrolisis menjadi glukosa. Namun, glukosa yang terlalu banyak menyebabkan inhibisi produk glukosa karena glukosa akan menempel pada sisi alosterik enzim, sehingga sisi aktif enzim amilase tidak dapat lagi ditempati oleh substrat.

\section{SIMPULAN}

Berdasarkan hasil penelitian yang telah dilakukan, maka dapat disimpulkan bahwa Bacillus megaterium dapat memproduksi enzim amilase pada suhu $37^{\circ} \mathrm{C}$ dengan aktivitas enzim amilase sebesar 
1,279 U/ml, pH 5,0 dengan aktivitas enzim amilase sebesar 1,241 U/,1 dan konsentrasi substrat 1,50\% dengan aktivitas enzim amilase sebesar 0,548 U/ml.

\section{DAFTAR PUSTAKA}

Ajayi, A. E., \& Fagade, O. E. (2006). Growth Pattern and Structural Nature of Amylases Produced by Some Bacillus Species in Starchy Substrates. African Journal of Biotechnology, 5(5): 440-444. Diakses dari http://www.academicjournals.org/AJB.

Carvalho, R. V., Corrreat., \& Da Silva, J. (2008). Properties of an Amylase from Thermophilic Bacillus sp. Brazil. Journal Microbiology, 39(1) :102-107. doi: 10.1590/S1517838220080001000023.

Choi, Y. W., Hodgkiss, I.J., \& Hyde, K. D. (2005). Enzyme Production by Endophytes of Brucea javanica. Journal of Agricultural Technology, 1(2), 55-56. Diakses dari https://www.semanticscholar.org/paper/En zyme-production-by-endophytes-of-Bruceajavanica-Choi-

Hodgkiss/828bboe288bcdaf65227780dabb7f 2663c73a7b9.

De Vos, P. (2009). Bergey's Manual of Systematic Bacteriology. John Willey \& Sons, 5. doi: 10.1002/9781118960608.

Desriani, U. M. S. P., Maria, B., Akhmad, R.,\& Puspita, L. (2014). Isolasi dan Karakterisasi Bakteri Endofit dari Tanaman Binahong dan Ketepeng Cina. Jurnal Kesehatan Andalas, 3(2), 89-93.doi:

https://doi.org/10.25077/jka.v3i2.33

Dheeran, P., Kumar, S., Jaiswal, J. Y., \&Adhikari, D. K. (2009). Characterization of Hyperthermostable $\quad \alpha$-Amylase from Geobacillus sp. IIPTN. Applied Microbiology and Biotechnology, 86(6): 1857-1866. doi: https://doi.org/10.1007/s00253-009-2430-9.

Maarel, V. (2002). Properties and Applications of Starch-converting Enzyme of the $\alpha$-amylase Family. Journal of Biotechnology, 94(2),137155. doi: 10.1016/sO168-1656(01)00407-2.

Mufarrikha, I., Roosdiana, A., \& Prasetyawan, S. (2014). Optimasi Kondisi Produksi Pektinase dari Aspergillus niger. Kimia Student Journal, 2 (1), 393-399. Diakses dari http://kimia.studentjournal.ub.ac.id/index.p hp/jikub/article/view/479/196.

Naiola, E. (2001). Karakterisasi Amilase dari Isolat Bakteri yang Berasal dari Bali dan Lombok. Jurnal Biologi Indonesia, 3 (1), 32-42. Diakses dari

https://media.neliti.com/media/publications /61030-ID-none.pdf.
Naiola, E. (2002). Karakterisasi dan Optimasi Media Produksi Amilase dari Aspergillus niger dan Aspergillus clavatus. Berita Biologi, 6(3):415421. Diakses dari http://ejournal.biologi.lipi.go.id/index.php/berita_biol ogi/article/view/1213

Ningsih, D. R., Rastuti, U., \& Kamaludin, R. (2012). Karakterisasi Enzim Amilase Dari Bakteri Bacillus amyloliquefaciens. Prosiding Seminar Nasional:Pengembangan Sumber Daya Pedesaan dan Kearifan Lokal Berkelanjutan II, November $2012 . \quad$ Diakses dari: https://www.neliti.com/publications/171850 /karakterisasi-enzim-amilase-dari-bakteribacillus-amyloliquefaciens\#cite.

Poedjiadi, A. (2006). Dasar-Dasar Biokimia Edisi Revisi. Jakarta : UI Press.

Purwoko, T. (2009). Fisiologi Mikroba. Jakarta: PT.Bumi Aksara.

Reddy, N. S., Nimmadagga, A., \& Sambasiva, R. 2003. An Overview of Themicrobial $\alpha-$ Amylase Family. African Journal of Biotechnology. 2(12), 645-648. Diakses dari: http://www.academicjournals.org/AJB.

Simanjuntak, M. T. (2003). Biokimia. Sumatera Utara: Fakultas Matematika dan Ilmu Pengetahuan Alam.

Soeka, Y. S. (2015). Kemampuan Bacillus licheniformis Dalam Menghasilkan Enzim $\alpha-$ amilase. Prosiding Seminar Nasional Masyarakat Biodiversitas Indonesia, 1 (5) : 11621166. doi: $10.13057 / \mathrm{psnmbi} / \mathrm{mo} 10534$.

Sudiana, I. M. (2002). Characteristic of CMC-ase of Bacillus sp. isolated from Gunung Halimun National Park. Berita Biologi, 6(1), 131-136. Diakses dari: http://ejournal.biologi.lipi.go.id/index.php/berita_bi ologi/article/view/1180

Supriyanti, F. M. T., \& Poedjiadi, A. (2007). DasarDasar Biokimia. Jakarta : Universitas Indonesia (UI-Press).

Tarigan, W. F., Sumardi., \& Setiawan, W.A. (2015). Karakterisasi Enzim Selulase dari Bakteri Selulolitik Bacillus sp (Skripsi, Prodi Biologi, Universitas Lampung). Diakses dari http://digilib.unila.ac.id/id/eprint/ 15915.

Tu, N., Doan, V., \& Le, T. 2015. Amylase Producing Bacillus megaterium To4 Isolated in Rach Lang Stream of Vietnam. Journal of Applied Pharmaceutical Science,5(10), 012-015. doi: 10.7324/JAPS.2015.501003.

Unakal, C., Kallur, R. I., \& Kaliwal, B. B. (2012). Production of $\alpha$-amylase using banana waste by Bacillus subtilis under solid state fermentation. European Journal of Experimental Biology, 2(4),1044-1052. Diakses dari http://www.imedpub.com/articles/productio 
n-of-amylase-using-banana-waste-bybacillus-subtilis-under-solidstatefermentation.pdf.

Vary, S. P. (2007). Bacillus megaterium from Simple Soil Bacterium to Industrial Protein Production Host. Applied Environment
Microbiology,76(5),957-67.doi: 10.1007/s00253-007-1089-3.

Vaseekaran, S., Balakumar, S., \& Arasaratnam, V. (2010). Isolation and Identification of a Bacterial Srain Producing Thermostable $\alpha$ Amylase. Tropical Agricultural Biology, 22(1): 1-11. doi: 10.4038/tar.v22i1.2603. 